UC-10

Iseued: December 1987

LA- -11167

DE88 005089

\title{
Determining Zirconium in Uranium by X-Ray Fluorescence
}

\author{
Calvin J. Martell \\ James M. Hansel
}

\begin{abstract}
DISCLAIMER
This report was prepared as an account of work sponsored by an agency of the United States Government. Neither the United States Government nor any agency thereof, nor any of their employees, makes any warranty, express or implied, or assumes any legal liability or responsibility for the accuracy, completeness, or usefulness of any information, apparatus, product, or process disclosed, or represents that its use would not infringe privately owned rights. Reference herein to any specific commercial product, process, or service by trade name, trademark, manufacturer, or otherwise does not necessarily constitute or imply its endorsement, recommendation, or favoring by the United States Government or any agency theriof. The views and opinions of authors expressed herein do not necessarily state or reflect those of the United States Government or any agency thereof.
\end{abstract}




\title{
DETERMINING ZIRCONIUM IN URANIUM BY X-RAY FLUORESCENCE
}

by

\author{
Calvin J. Martell and James M. Hansel
}

\begin{abstract}
Various concentrations of zirconium in uranium are determined by dissolving $2.5 \mathrm{~g}$ of the uranium sample. We add an aliquot of sample solution plus the internal standard, yttrium, to a $10-\mathrm{m} \ell$ volumetric flask and pour this solution into an $x$-ray cell that is covered with Mylar film. Standards and samples in $x$-ray cells are placed in an $x$-ray fluorescence wavelength instrument where the $K_{\alpha}$ line for both zirconium and yttrium are read. We then compare the ratio of the intensities of zirconium and yttrium for a sample with those for standards. The relative standard deviation for $1 \%$ and $5 \%$ zirconium is $0.6 \%$ and $0.08 \%$, respectively, with an accuracy of $100.3 \%$.
\end{abstract}

\section{INTRODUCTION}

Zirconjum. a detector element in uranium. is used to measure neutron energies of underground nuclear explosions. To properly determine the strength of the unclear device. we must know the concentration of the zirconium in the uranium. We are able to determine the zirconium in the uranium without doing a separation becauce of the relatively high levels of zirconium. Previously. chemists ${ }^{1}$ had been able to determine $5 \%$ to $50 \%$ zirconium in uranium. A uranium $\mathrm{L}_{\beta_{5}}$ line coincides with the zirconium $\mathrm{K}_{\alpha}$ line. and a correction factor is applied for this. We add yttrium as an internal standard at the beginning of the analysis to achieve the best precision possible. The yt trium compensates for any changes that may occur in the sample during processing. We transfer the solution containing uranium. zirconium. and $y$ ttrium to a $10-\mathrm{m} \ell$ volumetric Hask and add a portion of this solution to an $x$-ray cell for the analysis.

\section{Equipment and Reagents}

In this work. we used the following equipment:

- Aluminum cell holder. 50-mm o.d.

- Analytical balance

- Mylar film. 6- $\mu \mathrm{m}$ thick

- Sample cells. x-ray. Chemplex. plastic. number 1430. 32-mm o.d.

- X-ray spectrometer: Siemens SRS 300 microprocessor-controlled sequential $x$-ray spectrometer system: rhodium-target $x$-ray tube

We also used the following reagents:

- Hydrochlorir acid. 12M

- Hydrofluoric acid. $10 \mathrm{M}$ 
- Nitric acid, $15.7 \mathrm{M}$

- Yetrium solution. $0.500 \mathrm{mg} / \mathrm{ml}$

- Zirconium solution. NBS SRM 2129. 10.00 \pm 0.01 $\mathrm{mig} / \mathrm{ml} \ell$

- Zirconium solution, $0.500 \mathrm{mg} / \mathrm{m} \ell$, from NBS SRM 2129

- Zirconium solution, $1.000 \mathrm{mg} / \mathrm{m} \ell$, from NBS SRM 2129

\section{PROCEDURE FOR DISSOLUTION OF URA- NIUM-ZIRCONIUM ALLOY SAMPLES}

1. Dissolve $2.5 \mathrm{~g}$ of the $\mathrm{U}-\mathrm{Zr}$ alloy to avoid problems with heterogeneity.

2. Take an appropriate aliquot for the sample cut. (This work should be doue in a hood using a hot plate and a heat lamp. Gloves should be worn for this work.)

3. Put the accurately weighed $2.5 \mathrm{~g}$ of sample in a 250 $\mathrm{m} \ell$ beaker. add $5 \mathrm{~m} \ell$ of $12 \mathrm{M} \mathrm{HCl}$, and cover the beaker. After the vigorous reaction has stopped, a large amount of black material, uranium and zirconium. will remain.

4. Cool, rinse the cover glass and beaker walls with water, then add approximately $1 \mathrm{~m} \ell$ of $15.7 \mathrm{M} \mathrm{HNO}_{3}$. Swirl the beaker and heat with the heat lamp for several minutes. We are trying to dissolve the finely divided uranium at this step. but it is difficult to see when this has been completed because of the presence of the dark metallic zirconium.

5. Rinse the cover glass and beaker walls with water and evaporate the sample to incipient dryness.

6. Add $5 \mathrm{~m} \ell$ of $15.7 \mathrm{M} \mathrm{HNO}$ after cooling.

7. ('over the beaker. place on a hot plate, and heat until reaction almost ceases and brown fumes are gone.

8. Remove beaker from hot plate and allow to cool.

9. Transfer the uranium solution and the undissolved zirconium particles to a $50-\mathrm{m} \ell$ Tefton beaker using a wash bot tle. It will be necessary to put some $10 \mathrm{M}$ $\mathrm{HF}$ in the 250-me beaker and heat briefly to dissolve the small amount of xirconium that creeps up the boaker wall. This HF-Zr solution should bo added to the Tefton beaker. Repeat this step threo timess to ensure the dissolution of all remaining zirconium particles.

i0. Place the Teflon beaker under a heat lamp to evaporate excess liquid. As the evaporation takes place, the $\mathrm{HNO}_{3}$ and $\mathrm{HF}$ should dissolve the zirconium. If it appears that all the zirconium will not dissolve, add more $10 \mathrm{M}$ HF.

11. Allow the solution to stand until it has been clear for some time, then transfer it to a volumetric flask of the appropriate size.

\section{ANALYSIS OF SAMPLES}

We pipet $2 \mathrm{~m} \ell$ of the $0.500-\mathrm{mg} / \mathrm{m} \ell$ yttrium solution into each $20-\mathrm{m} \ell$ sample beaker, add the appropriate size aliquot of the sample, and evaporate this solution so that it fits into a $10-\mathrm{m} \ell$ volumetric flask. We then transfer a portion of this solution to an $x$-ray cell and cover the cell with $6-\mu$ m-thick Mylar film. Next, we place the covered $x$-ray cell containing our sample solution in an aluminum cell holder, which also has a Mylar cover. The sample solution is excited by the rhodium-target $x$-ray tube. We measure the following $2 \theta$ settings for $60 \mathrm{~s}$ each:

$\begin{array}{lll}\frac{2 \theta}{22.16} & & \text { Measurement } \\ 22.56 & & \text { Background I } \\ 23.80 & & \mathrm{Y} \mathrm{K}_{\alpha} \\ 24.40 & & \text { Background 2 } \\ 22.16 & & \text { Background 3 } \\ 23.04 & & \mathrm{UL}_{n} \\ 24.40 & & \text { Background 4 }\end{array}$

We analyze the samples with the spectrographic parameters shown in Table I:

\begin{tabular}{ll}
\hline \hline TABLE 1. X-Ray Operating Parameters \\
\hline X-ray tube & Rhodium \\
Potential & $60 \mathrm{kV}$ \\
Current & $50 \mathrm{~mA}$ \\
Counters & Scintillation and Flow \\
Analyzing crysta! & $\mathrm{LjF}$ \\
Soller slit & Fine \\
Counting time & $60 \mathrm{~s}$ \\
\hline
\end{tabular}




\section{STANDARDS}

Low Zirconium Levels Using $500 \mathrm{mg}$ of Uranium Sample

We prepare standards cont aining known antomots of zirconimu and yetrimm as listed below:

\begin{tabular}{|c|c|c|c|}
\hline $\begin{array}{l}\text { itandard } \\
\text { No. }\end{array}$ & $\begin{array}{l}\text { Zirconiumn } \\
\text { (ming) }\end{array}$ & $\begin{array}{c}\text { Ytuinm } \\
(m g)\end{array}$ & $\begin{array}{c}\text { Iranilum } \\
\text { (min) }\end{array}$ \\
\hline $\mathrm{Zr}-1$ & $0.00(0)$ & 2.0000 & 500 \\
\hline $\mathrm{Zr}-2$ & 0.0000 & 2.000 & 500 \\
\hline $\mathrm{Zr}-3$ & $2.0(x)$ & 2.000 & 500 \\
\hline$Z r-4$ & 2.(0) & 2.000 & 500 \\
\hline$Z r-\bar{j}$ & 5.0010 & 2.0000 & $5(30)$ \\
\hline$Z r-6$ & 5.0000 & 2.0000 & 500 \\
\hline
\end{tabular}

Figure 1 shows a plot of int.nsity ratios $(\mathrm{Zr} / \mathrm{Y})$ vs concentration for low percentiage levels of zirconinm.

\section{Higher Levels of Zirconium Using $100 \mathrm{mg}$ of Uranium Sample}

We prepare standards cont aining known amounts of zirconium and $y$ tt? inm as listed below:

\begin{tabular}{|c|c|c|c|}
\hline $\begin{array}{c}\text { Standard } \\
\text { No. }\end{array}$ & $\begin{array}{c}\text { Zirconium } \\
\text { (mg) }\end{array}$ & $\begin{array}{l}\text { Yttrium } \\
\text { (mg) }\end{array}$ & $\begin{array}{l}\text { Uranium } \\
\text { (mg) }\end{array}$ \\
\hline $\mathrm{Zr}-\mathrm{I}$ & 0.000 & 2.000 & 100 \\
\hline $\mathrm{Zr}-2$ & 0.000 & 2.000 & 100 \\
\hline $\mathrm{Zr}-3$ & 3.000 & 2.000 & 100 \\
\hline $\mathrm{Zr}-4$ & 3.000 & 2.000 & 100 \\
\hline $\mathrm{Zr}-5$ & $5 .(1) 0$ & 2.000 & 100 \\
\hline $\mathrm{Zr}-6$ & 5.000 & 2.000 & 100 \\
\hline
\end{tabular}

STANDARO CURYE FOR ZIRCONIUM (LOW)

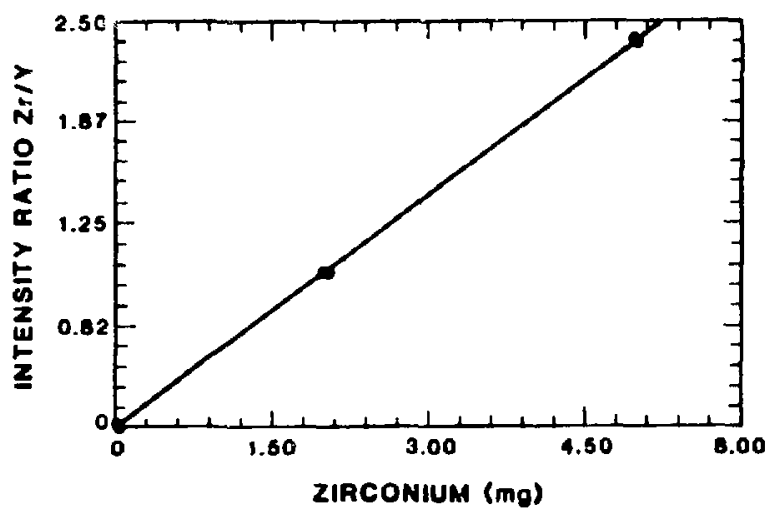

Fig. 1. Intensity vs concentration of low percentage Jevels of zirconium.

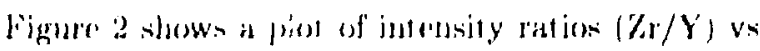
concentration for high perecontage levelo of zircominum.

\section{CALCULATIONS}

\section{Low Zirconium Levels Using $500 \mathrm{mg}$ of Ura- nium Sample}

The Sicrnens spectronctor gives net intensity values for the zirconium $K_{\alpha}$. yttrium $K_{r x}$. and uranium $L_{r_{t}}$ praks. Standards $\mathrm{Zr}-1$ and $\mathrm{Zr}-2$ contain no zirconium so the intensity values at the zirconium $K_{\alpha}$ sedting for these two will be due solely to uranium $\mathrm{L}_{\beta_{6}}$. The ratio of the uranium lines $L_{\beta_{b}} / L_{n}$ is about 2.7500 . With this ratio and the intensity of the uranium $L_{n}$ line. a correction can be made for the presence of the weak uranium line under the zirconium line. We multiply the ratic of the two uranium lines $\left(\mathrm{L}_{\beta_{b}} / \mathrm{L}_{n}\right)$ times the intensity of the uranium $L_{n}$ line and subtract the result from the intensity of the zireonium $K_{a}$ plus the uranium $\mathrm{L}_{\widehat{B}_{6}}$ line. The corrected zirconium intensity is then divided by the intensity of the yttrinm line. The values are expressed as counts per second. Wo do a least squares fit for the standards relating $\mathrm{Zr} / \mathrm{Y}$ ratios vs the zirconium concentrations. To calculate the concentrations of zirconium in the analyzed samples. we use the coefficients for the equation representing this standard curve.

\section{Higher Levels of Zirconium Using $100 \mathrm{mg}$ of Uranium Samples}

At these higher intensities for zirconium and with much lower amounts of uranium, we read only the zirconium and yttrium lines without backgrounds and do

StANDARD CURYE FOR zinCONIUM (HIGH)

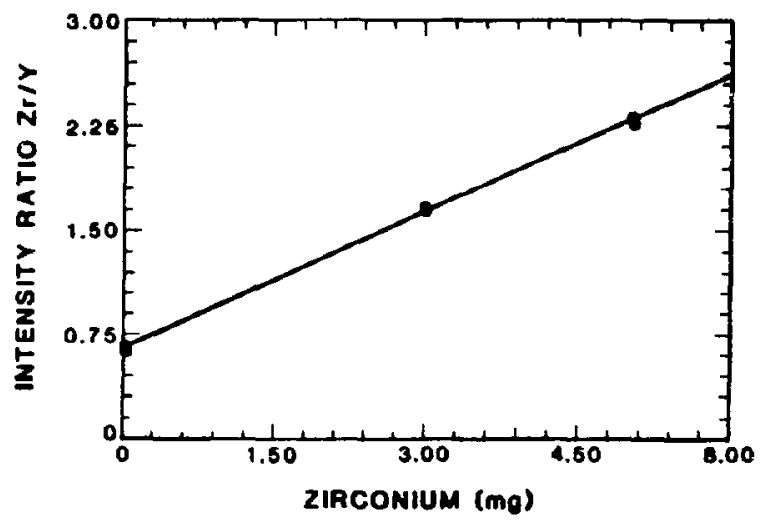

Fig. 2. Intensity vs concentration of high percentage levels of zirconium. 


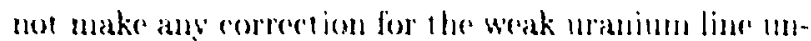
derlying the zirconium lino. Wo do a loast squares lit for the standards alat ing $/ \mathrm{r} / \mathrm{S}$ ratios vs the zirconium concentrations. To calculate the concentration of zircomium in the analyzed samplese. wo use the coofficionts for the equation represesting this standard curvo.

\section{PRECISION}

To establish the precision of the method. we propared four sots of zirconit.m samples using solutions prepaled from the NBS SRM 2129 \%irconium standard. Next. we pipetted the appropriate amount of the zirconium solution into six beakers and added yttrinn. the internal standard. and then the uranium sohtion. Theses semples were then analyod accoreding to the Analysis of ciamples section. The results are shown in Table Il. The average relative standard deviation for $0.5 \%$ ic $5.0 \%$ zireomimu is $0.8 \% \%$.

TABLE II. I'recision of Mathod (Low-Level Zirconiumin)

\begin{tabular}{ccc}
\hline $\begin{array}{c}\text { Zirconium } \\
(\%)\end{array}$ & $\begin{array}{c}\text { Number of } \\
\text { Determinations }\end{array}$ & $\begin{array}{c}\text { Relative Standard } \\
\text { Deviation } \\
(\%)\end{array}$ \\
\hline 0.5 & 6 & 1.60 \\
1.0 & 6 & 0.73 \\
3.0 & 6 & 0.53 \\
5.0 & 6 & 0.50 \\
\hline
\end{tabular}

\section{ACCURACY}

The accuracy of the method was determined with solutions prepared from the NBS SRM 2129 standard. We prepared four levels of zirconium samples

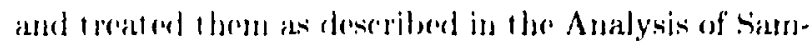
ples section: the results are givess in Thable IIJ. The average recovery for the sange of $0.5 \%$ to $5.0 \% \%$ zirese milum is 1100.34 ".

\begin{tabular}{ccc}
\hline \multicolumn{2}{c}{ TABLE III. Accuracy of Mothod } & \\
\hline $\begin{array}{c}\text { Zirconium } \\
\text { Added }\end{array}$ & $\begin{array}{c}\text { Number of } \\
\text { Determinations }\end{array}$ & $\begin{array}{c}\text { Zirconium } \\
\text { Recovery } \\
(\%)\end{array}$ \\
\hline 0.5 & 6 & 99.89 \\
1.0 & 6 & 100.88 \\
3.0 & 6 & 99.76 \\
5.0 & 6 & 100.73 \\
\hline
\end{tabular}

\section{DISCUSSION}

We have described the analysis of uranium for $0.5 \%$ to $5.0 \%$ zirconium using two sots of s1andards. low and high levels of zirconium. and are attempting to match standards with samples as closily as possible. We could have taken other amounts of sample. say $50 \mathrm{mg}$. for a different combination of zirconjum in uranium. The actual amount of zirconium may be similar in each set. but the important difference is that the low-level set of standards contains 500 $\mathrm{mg}$ of uranium and the high-level set contains only 100 mg of uranium.

\section{REFERENCE}

1. E. A. Hakkila. R. G. Hurley. and G. R. Waterbury. "X-ray Fluorescence Spectrometric Determination of Zirconium and Molybdenum in the Presence of Cranium." Analytical Chemistry 36. 20942097 (1964). 